PSYCHOSOCIAL ANALYSIS OF ETA’S VIOLENCE LEGITIMATION DISCOURSE

Title: Psychosocial analysis of ETA’s violence legitimation discourse.

\author{
Ana Varela-Rey - University of Barcelona \\ Álvaro Rodríguez-Carballeira - University of Barcelona \\ Javier Martín-Peña - University of Barcelona
}

Recibido: 16 de enero de 2012

Aceptado: 24 de abril de 2012

Revista de Psicología Social

\begin{abstract}
This study analyses the fundamental components shaping the violence legitimation discourse of ETA (Euskadi Ta Askasuna). With this aim, a category system has been built, which organizes the psychosocial processes identified in previous studies related to violence legitimation. Based on the proposed category system, a content analysis was conducted on 21 statements of ETA released between 1998 and 2011. An intra-observer and inter-observer reliability analysis reveals a high level of stability and replicability of the categorization. The results show, firstly, that outgroup components have a predominant presence over ingroup ones. Secondly, in the components hierarchy, we observe that elements referring to identity come in first place, followed in similar frequencies by those related to violence representation and the definition of the situation.
\end{abstract}

Keywords: Discourse, ETA, legitimation, Political violence, terrorism. 


\section{PSYCHOSOCIAL ANALYSIS OF ETA’S VIOLENCE LEGITIMATION DISCOURSE}

Título: Análisis psicosocial del discurso legitimador de la violencia de ETA.

\section{Resumen}

Este artículo analiza los componentes fundamentales que configuran el discurso legitimador de la violencia de ETA (Euskadi Ta Askatasuna). Con este objetivo, se construye un sistema de categorías, el cual organiza los procesos psicosociales identificados en investigaciones previas relacionadas con la legitimación de la violencia. A partir del sistema de categorías propuesto, se realiza un análisis de contenido en 21 comunicados de ETA publicados entre 1998 y 2011. El análisis de fiabilidad intraobservador e interobservador muestra una alta estabilidad y replicabilidad de la categorización. Los resultados muestran, en primer lugar, que los componentes exogrupales son predominantes respecto a los endogrupales. Segundo, en la jerarquización, se observa la preminencia de los elementos referidos a la identidad, seguido por frecuencias similares los relacionados con la representación de la violencia y la definición de la situación.

Palabras clave: Discurso, ETA, legitimación, violencia política, terrorismo.

\section{ACKNOWLEDGMENTS}

This research was development as part of the Ph.D. Program in Psychosocial Intervention of the University of Barcelona. The work was supported by the Spanish Ministry of Science and Innovation (Grant PSI2010-16098), and the Catalan Agency for Management of University and Research Grants and the International Catalan Institute for Peace (Grant 2010RICIP00012). 
PSYCHOSOCIAL ANALYSIS OF ETA'S VIOLENCE LEGITIMATION DISCOURSE Correspondence with authors

Ana Varela-Rey: University of Barcelona. ana.varela@ub.edu. Phone: +34 653622402.

Social Psychology Department. Passeig Vall d’Hebrón, 171, Edifici de Ponent, 08035

Barcelona 


\section{PSYCHOSOCIAL ANALYSIS OF ETA’S VIOLENCE LEGITIMATION DISCOURSE}

The study of violence legitimation is fundamental in conflict analysis and possible resolution alternatives. The use of violence fosters social rejection. For this reason, the aggressor group requires of discourse to legitimize violence in order to eliminate or reduce its negative impact and avoid losing the social support of its members and sympathizers (Sabucedo, Barreto, Borja, López-López, Blanco, De la Corte, \& Duran, 2004). In addition, as Van den Broek (2004) highlights, a discourse that justifies violence enables violent acts to get a meaning and to frame them in an explicative context. Hence, violence legitimation becomes a key aspect in the political violence strategy.

In this regard, violence legitimation discourses have a twofold role that has great importance for the aggressor group. First, they have a communicative role, in the sense that it enables to spread the ideology and makes the group more visible. Second, they have a persuasive role, as these types of discourses seek to perform to an audience and to stimulate beliefs within the group itself, with the aim of achieving the legitimacy of its actions (BorjaOrozco, Barreto, Sabucedo, \& López-López, 2008). It is in this latter function where intra and intergroup psychosocial processes of influence and persuasion are decisive. In this sense, the adoption of a psychosocial approach allows to frame the behaviour within the particular context in which the violence takes place. In addition, it facilitates a better understanding of these processes of the violence legitimation discourse (De la Corte, Kruglanski, De Miguel, Sabucedo, \& Díaz, 2007).

As Van Dijk (2006) notes, the study of discourse enables an understanding of the social representations that the discourse contains. Social representations define the social identity of the group and the ideological necessary constructions to justify the violence. Therefore, the study of the violence legitimation discourse using statements can be useful to identify points and structures related to social representations and, also, to help defining terrorist strategies (Crenshaw, 2000). 


\section{PSYCHOSOCIAL ANALYSIS OF ETA’S VIOLENCE LEGITIMATION DISCOURSE}

Hence, the objective of this research is to analyze, from an empirical perspective, the psychosocial components that build the violence legitimation discourse of ETA (Euskadi Ta Askatasuna). With this aim, we have conducted a content analysis of 21 statements of ETA published between 1998 and 2011.

\section{Studies on terrorism from a psychosocial perspective}

In this section, different studies on terrorism that take a psychosocial perspective are reviewed, with special emphasis on previous specific studies on the legitimation discourse of ETA.

Constructive elements of the legitimation discourse of terrorism

Of the different studies in the field of discourse and violence legitimation (e.g., Sabucedo, Blanco, \& De la Corte, 2003; Van Den Broek, 2004; Borja, Barreto, Alzate, Sabucedo, \& López-López, 2009; Prentice, Taylor, Rayson, Hoskins, \& O’Loughlin, 2010; Reinares, 2011), Sabucedo, Rodríguez-Casal and Fernández-Fernández (2002) list some of the elements that build the violence legitimation discourse (see Table I).

--- Add Table I approximately here ---

According to these authors, the justification of violence has two fundamental objectives; first, to provide the group with arguments to continue with the conflict and, second, to preserve a positive image of the group. Therefore, the violence legitimation would take shape from a highly salient conflict for the ingroup; who blames the adversary for the situation of violence and delegitimizes the victims that result from the ingroup violence. In addition, the ingroup presents itself as the main victim of the conflict. 


\section{PSYCHOSOCIAL ANALYSIS OF ETA’S VIOLENCE LEGITIMATION DISCOURSE}

Hence, in the analysis by Sabucedo et al. (2002) on the violence legitimation discourse, we can identify three central subjects. First, identity enables the ingroup vs outgroup differentiation. Second, the definition of the situation, which corresponds to the definition of a "highly salient conflict for the aggressor group". Third, the representation of violence, discussed in the classification of Sabucedo et al. (2002) in terms of "blaming the adversary on the situation of violence" and "victimization of the aggressor group”. Let us now discuss these themes.

\section{Polarized identities}

As many social-movements theories have discussed, when people participate in protest actions, the identification with the group is a fundamental component (Gamson, Crotequ, Hoynes, \& Sassont, 1992; Brewer, 1996; Bar-Tal, 2000; Klandermans, 2002). It is for this reason, that the component of identity is an essential element for groups using violence as a strategy for achieving their aims and it is, also, decisive in the justification of violence.

Tajfel (1981) explains, in his social identity theory, how the processes of comparison, categorization, identification and psychological distinctiveness enable intergroup distinctiveness to be established, from which the images of the ingroup and the outgroup are developed. As Brewer (1996) discusses, the psychological distinctiveness of the group entails the recognition and the legitimation of symbols and narratives of the group itself, so as to increase the intragroup similarities and exaggerate differences with the intergroup. Hence, in highly polarized contexts, these identity processes are the basis for confrontation.

In the same vein, Tajfel (1981) also introduces the idea of "group borders”, which refers to the situation of the group in the social conglomerate. The more threatened the group feels and the more it perceives the situation as "highly salient and essential" to its existence, 


\section{PSYCHOSOCIAL ANALYSIS OF ETA’S VIOLENCE LEGITIMATION DISCOURSE}

the more extreme will its reactions become (Erikson, 1968; Sabucedo et al., 2002). Therefore, if the group defines its situation as harmful for itself, this would become a decisive element to take action (Goldstone, 1980; Gamson et al., 1992; Javaloy, Rodríguez, \& Espelt, 2001).

The processes of intergroup attribution as instruments of legitimation

The construction of the social and personal identity requires, also, of attributional elements. As Huddy (2001) notes, social categorization is accompanied by perceptual distortion, leading to favoritism towards those things considered to be belonging to the group, but distinctiveness with respect to other groups. It is through these attributional processes how the members of the group explain their own behaviour and those of other groups (Hewstone, 1989; Hewstone, Rubin, \& Willis, 2002).

In this regard, as Fisher and Kelman (2011) point out, perceptual processes contribute significantly in fostering the conflict and, particularly, its escalation and perpetuation by feeding the images created of each group involved. In this line, Sherif and Sherif (1969 argue that these processes encourage hostility between groups and the external attribution of blame through erroneous causal perception. At the same time, these attributional processes protect the positive image of the group and help in the formation of a negative image of the other (Pettigrew, 1979, 1998).

\section{Construction of rationalizations for violence legitimation}

The violence legitimation discourse also needs for the construction of rationalizations as a way to justify the violent actions of the group. Kelman and Hamilton (1989) define three psycho-sociological processes that facilitate the participation of people in violent actions (legitimation by recognized authorities, dehumanization of the adversary, and habituation to violence). In addition, Gamson et al. (1992) outline the components of the collective action 


\section{PSYCHOSOCIAL ANALYSIS OF ETA’S VIOLENCE LEGITIMATION DISCOURSE}

of the group as the perception of the situation as unjust, the existence of a group identity, and considering the group collective action as an effective tool.

Thus, these psycho-sociological processes would be used in the construction of the rationalizations of the violent legitimation.

These rationalizations not only have the function of a moral justification of the violence, but also, as Bandura (1999) terms it, of moral disengagement. Bandura's moral disengagement enables the sense of moral responsibility to be diminished, displacing and minimizing the consequences of violent actions. Then, moral disengagement is a process of social redefinition where the adversary is dehumanized and blamed for his own suffering (McAlister, Bandura, \& Owen, 2006).

\section{Considerations on ETA}

Having reviewed some of the components shaping the violence legitimation discourse, we now introduce some considerations about ETA. The emergence of ETA on the Basque political scene in 1959 was conditioned by the Francoist dictatorship. ETA sought to redefine and promote Basque nationalism. ETA established two political objectives as the only possible routes to recover freedom: The independence of "Eukal Herria" with respect to Spain and France, and socialism. It is worth mentioning that the use of violence as a fighting strategy did not appear explicitly in its early organizational principles; however, the military wing did feature in its organizational structure (Segura, 2009). In fact, violence has been a constant trait as a strategy and differential feature; although, the strategic development of ETA has seen several tactical and technical modifications (Sánchez-Cuenca, 2008, 2009). 


\section{PSYCHOSOCIAL ANALYSIS OF ETA’S VIOLENCE LEGITIMATION DISCOURSE}

On 20 October 2011, ETA announced through a statement "the definitive cessation of its armed activity”. The statement was released few days after an International Conference ${ }^{1}$ held in San Sebastián. This conference concluded with five points, of which the first referred to "the definitive cessation of armed activity" on the part of ETA.

\section{Objective of the study}

As noted above, there has been a flurry of research on the psychosocial analysis of ETA’s discourse. Sabucedo et al. (2004), Barreto and Borja (2007) and Borja-Orozco et al. (2008) highlight that this sort of studies can provide a greater understanding of the keys of the use of violence, for which legitimation and justification of violence are essential. Therefore, this paper adds to the literature by analyzing attributional and perceptive processes those contribute to a particular construction of the social reality. This construction seeks to adjust itself to the purposes of the own ideology. Hence, as mentioned in the introduction, this study empirically investigates the underlying psychosocial processes in the construction of the violence legitimation discourse of ETA. To this end, a category system considering the psychosocial processes is proposed. The category system is used to conduct a content analysis of ETA’s statements.

\section{Method}

Type of investigation

In order to analyze the fundamental components shaping the violence legitimation discourse of ETA, a content analysis has been performed. Content analysis is a systematic

\footnotetext{
${ }^{1}$ The Peace Conference, held in San Sebastian on 17 October 2011, had the participation of international personalities from politics and peace, such as Kofi Annan, Bertie Ahern, Gro Harlem Brundtland, Pierre Joxe, Gerry Adams, and Jonathan Powell.
} 


\section{PSYCHOSOCIAL ANALYSIS OF ETA’S VIOLENCE LEGITIMATION DISCOURSE}

and objective research method of analyzing documents to describe and quantify the aim of the study (Elo and Kyngäs, 2008). According to these authors, inductive content analysis moves from a specific to a general scope, and it is recommended in case the former knowledge of the phenomenon is fragmented or not enough.

\section{Material}

Taking into account the difficulty in accessing inside information, we use the statements that ETA releases through mass media in order to analyze the discourse of ETA.

The sample consists of 21 statements of ETA released between 1998 and 2011. These documents were gathered from newspaper web pages, primarily GARA, but also Deia, El Diario Vasco, El Mundo and El País.

Sánchez-Cuenca (2008) differences three main periods in the strategic development of ETA: a) Stage of the revolutionary war; b) Stage of the war attrition strategy; and c) Stage of the Nationalist front. All the statements analyzed correspond to the latter stage, which was characterized by the "socialization of suffering". 2

\section{Procedure}

In first place, five statements were selected to carry out a pilot test. The analysis units were separated and a first contents analysis was performed on them, obtaining an extensive categorization of an inductive type. In the light of the revised theoretical framework and the results of previous studies quoted above, the initial categories were regrouped and endowed with a structure, configuring the category system to be used. In accordance with the guides on

\footnotetext{
${ }^{2}$ Note that the last statement, dated 20 October 2011, in which ETA announced "the definitive cessation of armed activity” could not be included as it was released after the analysis was conducted.
} 


\section{PSYCHOSOCIAL ANALYSIS OF ETA’S VIOLENCE LEGITIMATION DISCOURSE}

content analysis (Krippendorff \& Bock, 2009), the coding instructions of the categories were written up, containing the name of the category, its precise definition, an example of this and the coding rule.

The coding of the 21 statements was performed using the software ATLAS.ti 6. The registration units were selected by the criterion of presence in the analysis unit and assigned to a category. With the aim of verifying the reliability and replicability of the category system, a second intrajudge coding was carried out, as well as a third coding by a second judge. Cohen's Kappa coefficient was used as a reliability coefficient of the two encoders (Kripperdorff \& Bock, 2009), using the PAWS-18 statistics package.

\section{Results}

The category system proposed organizes the components of the violence legitimation discourse around three central subjects: a) "the definition of the situation", b) "the identity", and c) "the representation of the violence". In addition, each of these subjects is subdivided into two to keep the dichotomous structure characteristic of the intergroup attribution dynamic.

--- Add Table II approximately here ---

Table II shows the results of the content analysis on the statements in decreasing order by their frequency of appearance. The results of the intrajudge and interjudge coding indicate a good level of reliability of the category system, with a stability and replicability rate of $\kappa=.95$ and $\kappa=.87$ respectively. Following, the results for each category are explained in more detail. Also, see Table III for examples of coded categories. 
PSYCHOSOCIAL ANALYSIS OF ETA’S VIOLENCE LEGITIMATION DISCOURSE

--- Add Table III approximately here ---

\section{Identity}

The categories related to identity are those which scored highest. In absolute terms, 129 codes were obtained, which corresponds to $38.3 \%$ of the total number of codes $(f=337)$. In the identity subject the "positive ingroup identity" and "negative outgroup identity" categories were distinguished, with the latter category reaching the highest frequency with 66 codes representing $19.6 \%$ of the total number of codes. The "negative outgroup identity" refers to the construction of a negative image of the other (outgroup) on the base of definitions, comparisons, and behavioural examples or associations with other groups which cause social rejection. The allusion to the other can mean the Spanish or French States, a political party, a place (e.g., Madrid) or even a particular person. For example:

"One of those responsible for this imposition was Ignacio U. M. While he paid Spanish taxes, while he worked for the good of Spain and he enriched himself through his work on the $\mathrm{TAV}^{3}$ tax, he refused to help in the fight for the freedom of Euskal Herria.” (Gara, 21-01-2009)

The "positive ingroup identity" consists of attributing the ingroup with positive characteristics and behaviours. In the statements, this process is seen through association with other socially accepted groups, presenting themselves as defenders of peaceful ways forward and underlining their capacity of dedication and the solitude of their activity. As with the previous category, the “we” can mean ETA, the Abertzale Left ${ }^{4}$ or the “Basques”.

\footnotetext{
${ }^{3}$ TAV stands for “Tren de Alta Velocidad”, in English “High Speed Train”.

${ }^{4}$ Term used to refer to organizations and political parties with a left-wing and Basque independence ideology.
} 


\section{PSYCHOSOCIAL ANALYSIS OF ETA’S VIOLENCE LEGITIMATION DISCOURSE}

"We have worked to try and overcome the institutional division and between States, in order to bring peace to our people based on justice and democratic rights.” (Deia, 16-09-1998)

\section{Representation of violence}

The "representation of violence" scored 109 codes, which corresponds to $32.3 \%$ of the total codes. This central subject is divided into two categories, “outgroup harmful violence” and "defensive ingroup violence”. The "outgroup harmful violence” appears more frequently in the statements, 58 codes of the 109 total codes, corresponding to $17.2 \%$ of the total codes of the statements. The "outgroup harmful violence" consists of attributing to the outgroup the responsibility for the situation of violence, accusing them of behaviours such as repression, interference, imposition, torture or detention. These behaviours make reference to violent direct actions, but also, in some cases, violence is attributed to the outgroup due to their omission. For example, see the following extract in reference to the bomb attack at Terminal 4 of Madrid-Barajas airport on 30 December 2006.

“Apart from wishing to firmly express that the aim of the armed action was not to cause any victims, we wish to denounce the fact that the car park was not evacuated or vacated in the long period of one hour, despite three calls explaining the exact place where the explosives were left.” (El Diario Vasco, 10-01-2007)

The second category, “defensive ingroup violence”, refers to the violence carried out by the ingroup as the only way out of the situation described in the previous category. Violence is referred as being defensive, efficient and committed. The ingroup presents itself as being on the receiving end of the violence perpetrated by the other.

\footnotetext{
"In first place, we wish to make it clear that the confrontation that has had as a result the kidnapping of the Basque citizen and the death of the French policeman was against ETA's wishes” (Gara, 04-04-2010).
} 


\section{PSYCHOSOCIAL ANALYSIS OF ETA’S VIOLENCE LEGITIMATION DISCOURSE}

The third central subject obtained 99 codes, which made up $29.4 \%$ of the total codes. This subject includes the categories of "illegitimate current situation" and "future situation aim”. Both categories scored similar points, 50 and 49 respectively in absolute terms. In the case of the statements made by ETA, the current situation is defined as illegitimate or unjust and serious for the ingroup. There is an allusion to the idea of the existence of an unresolved conflict, a situation that does not conform to the law, which persists independently to the activity of ETA. In general, this category refers to an absence of democracy or a lack of rights.

“The democratic process cannot be carried out without the participation of the State. Its participation will have to consist, at least, in abandoning its interference in Euskal Herria. A truce or ceasefire by ETA will not bring about a democratic process as a consequence.” (Gara, 31-12-2009)

In contrast, the "future situation aim" is defined as legitimate. This is expressed through the idea of opportunity, the existence of a project, which in the case of ETA is "Euskal Herria”, and that it is a project for all Basque citizens.

"ETA wishes to take steps forward to overcome the institutional division and move towards an independent State. Thousands of votes in favour of a political change and thousands voices for the future of these people. ETA is also in favour of the process of liberation.” (El Pais, 05-06-2007)

To sum up, three main results arise from the content analysis. First, the category system allows identifying the hierarchy of the components of ETA's violence legitimation discourse. Second, the categories related to the construction of identity are preeminent. Third, categories related to the outgroup show a higher frequency than those referring to the ingroup. 


\section{PSYCHOSOCIAL ANALYSIS OF ETA’S VIOLENCE LEGITIMATION DISCOURSE}

\section{Discussion}

The category system tries to reflect the set of social beliefs that shape the violence legitimation discourse. It becomes an interpretative framework in which to organize reality, giving it social and symbolic meaning (Gamson et al, 1992). Social beliefs are not only based on a categorization strategy, but also this categorization is accompanied by the attribution of a positive or negative value (Pettigrew, 1979, 1998; Van Dijk, 2003). Therefore, attributional processes are the necessary instruments for the organization of the violence legitimation discourse.

In this regard, literature on the use of political violence in Colombia, (Sabucedo et al., 2004; Sabucedo, Barreto, Borja, De la Corte, \& Durán, 2006; Borja-Orozco et al., 2008; Alzate, Durán, \& Sabucedo, 2009; Barreto, Borja, Serrano \& López-López, 2009) show this dual attribution function of the violence legitimation discourse. These studies indicate the need to organize a discourse that links the social situation of injustice and the responsibility of the adversary group. With regard to the case analyzed in this paper, it can be seen how the category referring to the definition of the current social situation as unjust provides beliefs on the formation of the negative identity of the adversary. In this way, undemocratic values, such as the lack of interest in resolving the conflict or exercising the imposition of power, are attributed to the outgroup as internal characteristics.

Concerning the processes that configure social identity (Tajfel, 1981), in the case of ETA, it can be seen that there is a greater presence of those related to the need for psychological distinctiveness from the other (Negative outgroup identity). In this line, Van den Broek (2004) indicates how the violence legitimation discourse can be aimed mainly at the members of the ingroup, as this gives them arguments to avoid external criticism and homogenize the group, thus reducing internal opposition. Hence, the ethical conflict arising 


\section{PSYCHOSOCIAL ANALYSIS OF ETA’S VIOLENCE LEGITIMATION DISCOURSE}

from the use of violence is eliminated or cushioned and, also, a positive image of the aggressor group is maintained, laying the responsibility of the conflict on the other group (Bar-Tal, 1996, 2000; Van Dijk, 2003). Furthermore, as Bar Tal (1996, 2000) indicates, the processes of dehumanizing the adversary are favoured along with the asymmetrical evaluation of the suffering (Sabucedo et al., 2004). These processes can undervalue and blame the victims for their situation, thus encouraging a secondary victimization and a situation of exclusion in a context of prolonged political violence (Martin-Peña, Opotow, \& Rodríguez-Carballeira, 2011).

With respect to violence, it is possible to distinguish between "originating violence" and "response violence". As Sabucedo et al. (2006) noted in reference to the case of Colombia, this differentiation has distinct ethical implications. In our analysis, this differentiation is also found. Regarding this, the attribution of the responsibility for the situation of violence to the adversary, presenting themselves as the recipients of the outgroup violence and classifying the violence exercised by the ingroup as defensive, contributes to build rationalizations aimed at moral justification (Bandura, 1999). In addition, ETA attributes to the violence a value of political efficiency in order to achieve its objectives, which could encourage its definition as the only alternative. The attribution of efficiency to violence as a strategy could be one of the elements to be taken into account in the abandonment of violence.

The definition of the situation also provides rationalizations for the use of violence (Tajfel, 1981; Bandura, 1999; Barreto et al., 2009). These categories (“illegitimate current situation" and "future situation aim") allow the discourse to be organized around more specific objectives (Kelman \& Hamilton, 1989), which in the case of ETA are of a political nature. Based on the scores obtained, both categories have a similar presence in the 


\section{PSYCHOSOCIAL ANALYSIS OF ETA’S VIOLENCE LEGITIMATION DISCOURSE}

statements. This could indicate the need to organize an alternative discourse to the current situation, which is defined as unfavourable for the ingroup. The alternative discourse could be based on an idea of the future that would strengthen the sense of an illegitimate current situation and introduce the willing of change through the existence of another project.

Hence, violence legitimation discourse becomes a form of action and social interaction, which persuasively communicates a range of beliefs through discursive and social practices and that, at the same time, can contribute to their reproduction in the social system (Van Dijk, 2003).

\section{Limitations, implications and future prospects}

One of the first limitations faced by this study is the complexity of the area of analysis on which it is based and the difficulties in collecting materials (see, also, Horgan, (2006)). We acknowledge that, the type of sampling selected for the study makes it difficult to generalize about the results. However, as Borja-Orozco et al. discuss, (2008, p. 572) "there are a series of common elements that contribute towards identifying what people consider to be a discourse in the political context”. In addition, the results of this paper support earlier findings by Sabucedo et al., 2002; Sabucedo et al., 2003; Van Den Broek, 2004; Borja et al., 2009; Prentice et al. 2010 and Reinares, 2011.

Regarding theoretical implications, this research aimed at improving the knowledge of the processes of legitimation and justification of violence in a specific context as is that of ETA's statements. It might be relevant to analyze the discourses as this kind of analysis allows to identify the beliefs contained within the discourses and assess the real situation in which the conflict is found. Also, it helps in the understanding of the development of the strategy, the definition of the problem and the selection of victims. 
PSYCHOSOCIAL ANALYSIS OF ETA’S VIOLENCE LEGITIMATION DISCOURSE

The legitimation discourse components of violence are, not only, a necessary instrument for the use and maintenance of violence on the part of the groups, but also, they include characterized images of the ingroup and outgroup that shape social identity. To transform these images to create inclusive identities, there is the need for some intragroup consensus in order to overcome the delegitimization and the dehumanization of the adversary (Borja et al., 2009). In addition, the study of violence legitimation discourses account for the hidden and automated attributional and perceptive processes, which can contribute significant information when designing strategies for prevention and conflict resolution.

Future research may be aimed at carrying out a thorough investigation of the categories system, favouring a more detailed analysis, including the development over time in function of the political-social context of the publication of the statements or expanding the sample studied. 
PSYCHOSOCIAL ANALYSIS OF ETA’S VIOLENCE LEGITIMATION DISCOURSE

\section{References}

Alzate, M., Durán, M., \& Sabucedo, J.M. (2009). Población civil y transformación constructiva de un conflicto armado interno: aplicación al caso colombiano. Universitas Psychologica, 8, 703-720.

Bandura, A. (1999). Moral disengagement in the perpetration of inhumanities. Personality and Social Psychology Review, 3, 193-209. Doi: 10.1207/s15327957pspr0303_3.

Barreto, I., \& Borja, H. (2007). Violencia política: algunas consideraciones desde la psicología social. Revista Diversitas-Perspectivas en Psicología, 3, 109-119.

Barreto, I., Borja, H., Serrano, Y., \& López-López, W. (2009). La legitimación como proceso en la violencia política, medios de comunicación y construcción de culturas de paz. Universitas Psychologica, 8, 737-748.

Bar-Tal, D. (1996). Development of social categories and stereotypes in early childhood: The case of "the Arab" concept formation, stereotype and attitudes by Jewish children in Israel. International Journal of Intercultural Relations, 20, 341370.

Bar-Tal, D. (2000). From intractable conflict through conflict resolution to reconciliation: Psychological analysis. Political Psychology, 21, 351-365. Doi: 10.1111/0162895X.00192. 
PSYCHOSOCIAL ANALYSIS OF ETA’S VIOLENCE LEGITIMATION DISCOURSE

Borja-Orozco, H., Barreto, I., Sabucedo, J.M., \& López-López, W. (2008). Construcción del discurso deslegitimador del adversario: gobierno y paramilitarismo en Colombia. Universitas Psychologica, 7, 571-583.

Borja, H., Barreto, I., Alzate, M., Sabucedo J.M., \& López-López, W. (2009). Creencias sobre el adversario, violencia política y procesos de paz. Psicothema, 21, 622-627.

Brewer, M.B. (1996). Who is “we”? Levels of collective identity and self-representations. Journal of personality and social psychology, 71, 83-93.

Crenshaw, M. (2000). The psychology of terrorism: An agenda for the 21st century. Political Psychology, 21, 405-420. Doi: 10.1111/0162-895X.00195.

De la Corte, L., Kruglanski, A., De Miguel, J., Sabucedo, J.M., \& Díaz, D. (2007). Siete principios psicosociales para explicar el terrorismo. Psicothema, 19, 366-374.

Elo, S., \& Kyngäs, H. (2008). The qualitative content analysis process. Journal of advanced nursing, 62, 107-115. Doi: 10.1111/j.1365-2648.200704569.x

Erikson, E.H. (1968). Identity, youth and crisis. New York: Norton.

Fisher, R.J., \& Kelman, H.C. (2011). Perceptions in conflict. In D. Bar-Tal (Ed.), Intergroup conflicts and their resolution (pp. 61-81). New York: Taylor and Francis.

Gamson, W., Crotequ, D., Hoynes, W., \& Sassont, T. (1992). Media images of the social construction of reality. Annual Review of Sociology, 18, 373-393. 
PSYCHOSOCIAL ANALYSIS OF ETA’S VIOLENCE LEGITIMATION DISCOURSE

Goldstone, J. (1980). The weakness of organization: A new look of Gamson’s strategy of social protest. American Journal of Sociology, 86, 1017-1042.

Hewstone, M. (1989). Causal attribution: From cognitive processes to collective belief. Oxford: Blackwell Publishers, Ldt.

Hewstone M., Rubin M., \& Willis, H. (2002). Intergroup bias. Annual Review of Psychology, 53, 575-604. Doi: 10.1146/annurev.psych.53.100901.135109

Horgan, J. (2006). Psicología del terrorismo. Barcelona: Gedisa.

Huddy, L. (2001). From Social to Political Identity: A Critical Examination of Social Identity Theory. Political Psychology, 22 (1), 127-156.

Javaloy, F., Rodríguez, A., \& Espelt, E. (2001). Comportamiento colectivo y movimientos sociales. Madrid: Pearson Educación, S.A.

Kelman, H. C., \& Hamilton, V.L., (1989). Crimes of obedience: Toward a social psychology of authority and responsibility. New Haven: Yale University Press.

Klandermans, B. (2002). How group identification helps to overcome the dilemma of collective action. American Behavioral Scientist, 45, 887-900. Doi: $10.1177 / 0002764202045005009$ 
PSYCHOSOCIAL ANALYSIS OF ETA’S VIOLENCE LEGITIMATION DISCOURSE

Krippendorff, K., \& Bock, M.A., (2009). The content analysis reader. California: SAGE Publications, Inc.

Martín-Peña, J., Opotow, S., \& Rodríguez-Carballeira, A. (2011). Amenazados y víctimas del entramado de ETA en Euskadi: un estudio desde la teoría de la exclusión moral. Revista de Psicología Social, 26, 177-190. Doi: 10.1174/021347411795448992

McAlister, A.L., Bandura, A., \& Owen, S.V. (2006). Mechanisms of moral disengagement in support of military force: The impact of Sept. 11. Journal of Social and Clinical Psychology, 25, 141-165. Doi: 10.1521/jscp.2006.25.2.141

Pettigrew, T. F. (1979). The ultimate attribution error: Extending Allport's cognitive analysis of prejudice. Personaliy and Social Psychology Bulletin, 5, 461-476. Doi: 10.1177/014616727900500407.

Pettigrew, T.F. (1998). Intergroup contact theory. Annual Review of Psychology, 49, 65-85. Doi: 10.1146/annurev.psych.49.1.65.

Prentice, S., Taylor, P.J., Rayson, P., Hoskins, A., \& O’Loughlin, B. (2010). Analyzing the semantic content and persuasive composition of extremist media: A case study of texts produced during the Gaza conflict. Inf. Syst. Front, 13, 61-73. Doi: 10.1007/s1076-010-9272-y.

Reinares, F. (2011). Patriotas de la muerte. Madrid: Grupo Santillana de ediciones S.A. 
PSYCHOSOCIAL ANALYSIS OF ETA’S VIOLENCE LEGITIMATION DISCOURSE

Sabucedo, J.M., Rodríguez-Casal, M., \& Fernández-Fernández, C. (2002). Construcción del discurso legitimador del terrorismo. Psicothema, 14, Supl., 72-77

Sabucedo, J.M., Blanco, A., \& De la Corte L. (2003). Beliefs which legitimize political violence against the innocent. Psicothema, 15, 550-555.

Sabucedo, J.M., Barreto, I., Borja, H., López-López, W., Blanco, A., De la Corte, L., \& Durán, M. (2004). Deslegitimación del adversario y violencia política: el caso de las FARC y las AUC en Colombia. Acta Colombiana de Psicología, 12, 69-85.

Sabucedo, J.M., Barreto, I., Borja, H., De la Corte, L., \& Durán, M. (2006). Legitimación de la violencia y contexto: análisis textual del discurso de las FARC-EP. Estudios de Psicología, 27, 279-291.

Sánchez-Cuenca, I. (2008). The persistente of nationalist terrorism: The case of ETA. Capítulo en preparación para: Kledja Mulaj (Ed) Violent Non-State Actors in Contemporany World Politics. Madrid: Working paper, Juan March Institute.

Sánchez-Cuenca, I., \& De la Calle, L. (2009). Domestic terrorism: The hidden side of political violence. The Annual Review of Political Science, 12, 31-49. Doi: 10.1146/annurev.polisci.12.031607.094133.

Segura, A. (2009). Euskadi. Crónica de una desesperanza. Barcelona: Alianza Editorial, S.A. 
PSYCHOSOCIAL ANALYSIS OF ETA’S VIOLENCE LEGITIMATION DISCOURSE

Sherif, M., \& Sherif, C. (1969). Psicología social. México: Harla.

Tajfel, H. (1981). Human groups and social categories. Cambridge: Cambridge University Press.

Van Den Broek, H. (2004). BORROKA - The legitimation of street violence in the political discourse of radical Basque nationalists. Terrorism and Political Violence, 16, 714736. Doi: 10.1080/095465590885141.

Van Dijk, T.A. (2003). Discourse and manipulation. Discourse \& Society, 17, 359-383. Doi: 10.1177/0957926506060250.

Van Dijk, T.A. (2006). Ideology and discourse analysis. Journal of Political Ideologies, 11, 115-140. Doi: 10.1080/13569310600687908. 
PSYCHOSOCIAL ANALYSIS OF ETA’S VIOLENCE LEGITIMATION DISCOURSE

Table I

Constructive elements of the legitimation discourse of terrorism

\section{Existence of a highly salient conflict for the group}

To define the situation in which the group is found as unjust and illegitimate. The solution lies in social change.

\section{Blame the adversary for the existing situation of violence}

To displace the responsibility of the situation of violence to the outgroup and present the ingroup as a defender of peaceful and willing to talk means.

\section{Delegitimization of victims}

To delegitimize through defamatory remarks.

\section{Victimization of the aggressor group}

The ingroup is presented as a victim of the situation

Note. Adapted from “Construcción del discurso legitimador del terrorismo” by J.M. Sabucedo, M.

Rodríguez-Casal and C. Fernández-Fernández, 2002, Psicothema, 14 supl., 72- 77 
PSYCHOSOCIAL ANALYSIS OF ETA’S VIOLENCE LEGITIMATION DISCOURSE

Table II

Category system and frequencies of the components of the violence legitimation discourse of ETA.

\begin{tabular}{|c|c|c|}
\hline Categories & $f$ & $\%$ \\
\hline IDENTITY & 129 & $38.3 \%$ \\
\hline Negative outgroup identity & 66 & $19.6 \%$ \\
\hline Positive ingroup identity & 63 & $18.7 \%$ \\
\hline REPRESENTATION OF VIOLENCE & 109 & $32.3 \%$ \\
\hline Outgroup harmful violence & 58 & $17.2 \%$ \\
\hline Defensive ingroup violence & 51 & $15.1 \%$ \\
\hline DEFINITION OF THE SITUATION & 99 & $29.4 \%$ \\
\hline Illegitimate current situation & 50 & $14.8 \%$ \\
\hline Future situation aim & 49 & $14.5 \%$ \\
\hline Total units of analysis & 337 & 100 \\
\hline Inter-observer reliability & $\kappa=.87$ & \\
\hline Intra-observer reliability ${ }^{1}$ & $\kappa=.95$ & \\
\hline
\end{tabular}

${ }^{\mathrm{T}}$ Note. Test-retest with 30 days of interval. 


\section{PSYCHOSOCIAL ANALYSIS OF ETA'S VIOLENCE LEGITIMATION DISCOURSE}

Table III

Examples of coded categories in the statements of ETA

Negative Outgroup Identity

IDENTITY

Positive Ingroup Identity

"France has not broken with its Jacobin past and continues to be one of the most centralized and reactionary countries when it comes to recognizing the existence of peoples.” (Gara, 14-06-2006)

"The enemy has tried to break this so that in one way or another, by spreading lies, disseminating leaks, creating and feeding supposed dissidents...but it has been in

vain.” (Gara, 31-12-2009)

"It is our profound desire, therefore, that the Abertzale Left is not left alone again in this task which is that of everybody's. But even if it were the case, we will continue onwards with the joy and same desire until now, following the path shown by thousands of Basques and gudaris (Basque soldiers).” (Deia, 16-09-1998)

"The struggle for the freedom of the Basque County has always guided the actions of ETA and, despite all the difficulties, we will continue with this responsibility.” (Gara, 05-09-2010)

\section{Outgroup harmful violence}

REPRESENTATION OF THE VIOLENCE

"The imposition of foreign laws, the linguistic and cultural genocide, the partition and the militarization of the territory, the police and parapolice murders, the raids and selective detentions, the systematic use of torture, the states of exception, special pacts and plans, criminal penitentiary policies, deportation, collaboration of regiona police forces and those of third countries, the closure of mass media, the outlawing of popular organizations, political formations and electoral candidates..., the list is endless. And this list of daily oppressions and humiliations is also hidden.” (El Pais,

21-06-2006)

\section{DEFINITION OF THE SITUATION}

Illegitimate Current Situation

"We must not close our eyes when faced with the situation suffered by Euskal

Herria. Because, however we look at it, the situation experienced by our people is extremely serious”. (Deia, 16-09-1998)

"Divided and humiliated, the Basque people cannot constitute itself freely as a "It is necessary to advance now in the start up of a new institutional framework which can guarantee the future of Euskal Herria.” (Gara, 14-06-2006)

"However, we have in sight the political keys to guarantee the present and the future nation. It was not able to decide freely neither its form of internal organization nor its relations with the French and Spanish States." (Gara, 14-06-2006) politicians pacts against the abertzale left and ending in this way with the impunity in order to

"In this task, and until the democratic conditions exist to defend all the projects in Euskal Herria, ETA expresses its determination to continue to strike at the structures Ex the Spanish State on all fronts and to continue defending Euskal Heria through the use of the arms.” (Gara, 09-09-2007)

of Euskal Herria: Self-determination and territoriality.” (El Pais, 05-06-2007) 